\title{
How Does Mytilus galloprovincialis Respond When Exposed to the Gametophyte Phase of the Invasive Red Macroalga Asparagopsis armata Exudate?
}

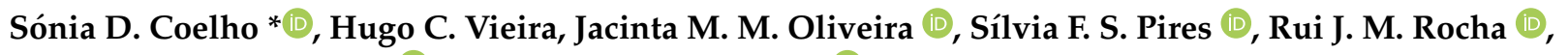 \\ Andreia C. M. Rodrigues (D), Amadeu M. V. M. Soares $(\mathbb{D}$ and Maria D. Bordalo \\ CESAM (Centre for Marine and Environmental Studies), Department of Biology, University of Aveiro, \\ 3810-193 Aveiro, Portugal; hugovieira@ua.pt (H.C.V.); jacintaoliveira@ua.pt (J.M.M.O.); \\ silviapires1@ua.pt (S.F.S.P.); ruimirandarocha@ua.pt (R.J.M.R.); rodrigues.a@ua.pt (A.C.M.R.); \\ asoares@ua.pt (A.M.V.M.S.); maria.bordalo@ua.pt (M.D.B.) \\ * Correspondence: sdcoelho@ua.pt
}

\section{check for} updates

Citation: Coelho, S.D.; Vieira, H.C.; Oliveira, J.M.M.; Pires, S.F.S.; Rocha, R.J.M.; Rodrigues, A.C.M.; Soares, A.M.V.M.; Bordalo, M.D. How Does Mytilus galloprovincialis Respond When Exposed to the Gametophyte Phase of the Invasive Red Macroalga Asparagopsis armata Exudate? Water 2021, 13, 460. https://doi.org/ $10.3390 /$ w13040460

Academic Editor: María Pilar Cabezas Rodríguez

Received: 21 January 2021

Accepted: 6 February 2021

Published: 10 February 2021

Publisher's Note: MDPI stays neutral with regard to jurisdictional claims in published maps and institutional affiliations.

Copyright: (c) 2021 by the authors. Licensee MDPI, Basel, Switzerland. This article is an open access article distributed under the terms and conditions of the Creative Commons Attribution (CC BY) license (https:// creativecommons.org/licenses/by/ $4.0 /)$.

\begin{abstract}
Asparagopsis armata is classified as an invasive species in Europe. Through the exudation of secondary metabolites, this macroalga holds a chemical defence against consumers, with potential toxic effects to native rocky shore communities. This study aims to evaluate the potential impact of A. armata (gametophyte) exudate in a native species, the mussel Mytilus galloprovincialis, in terms of biochemical and organismal effects. The $96 \mathrm{~h}-\mathrm{LC} 50$ was $3.667 \%$ and based on it, exudate concentrations $(0.25 ; 0.5 ; 1 ; 2 \%)$ were determined to further sublethal experiments. These sublethal concentrations caused no oxidative damage in the digestive gland since lipid peroxidation and protein carbonylation were not affected. Nevertheless, there was a significant rise in the electron transport system activity and total glutathione content in muscle, suggesting an increased nonenzymatic antioxidant capacity and consequent energy consumption to cope with potential prooxidant compounds. This might have contributed to the observed decline in cellular energy allocation of the exposed mussels. At the organismal level, clearance capacity declined along the concentration gradient. Moreover, the number of functional byssuses decreased with increasing concentrations and a significant reduction in their attachment strength was observed. These findings suggest that the presence of A. armata may compromise M. galloprovincialis integrity in the invaded coastal areas.
\end{abstract}

Keywords: invasive macroalgae; marine; biochemical markers; clearance rate; byssus production

\section{Introduction}

The continuous proliferation of invasive seaweeds has grown a great concern considering their impacts on native marine communities, mainly because they naturally threaten the availability of resources compromising the natural ecosystem functioning [1]. The red marine macroalgae Asparagopsis armata Harvey, 1855 (Bonnemaisoniales, Rhodophyta), native from southern Australia and New Zealand, is identified as an invasive species and widely distributed in the Mediterranean and Atlantic coasts of Europe including Portugal [2,3]. This temperate alga can overcome the ecological barriers and colonise diverse environmental conditions, mainly due to its fast growth rate, lack of predators and its effective spread, both through the tetrasporophyte floating balls and the gametophyte phase that hooks onto floating material $[4,5]$. A armata sets mainly in the coastal low intertidal zone extending to the upper meters of the subtidal zone $[3,6]$. Therefore, it competes for resources (mainly space and nutrients) with specific native species, such as epifaunal assemblages. Furthermore, this macroalga is adapted to strong physicochemical changes $[7,8]$, characteristic from this zone, imposed by wave action and the ebb and flow of the tide. These tidal cycles lead to the formation of microenvironments within intertidal tide pools, wherein the organisms face adverse conditions [9]. Like other seaweeds (particularly concerning in case 
of invasive macroalgae $[10,11])$, A. armata is known to exude a wide array of secondary metabolites with potentially deleterious effects, including a large number of halogenated compounds (e.g., haloketones, haloacids and haloforms) [12,13]. This mixture is usually produced as a chemical defence against consumers, epiphytes such as bacteria and may act in space competition (allelopathy) $[4,14]$. Exudation of such compounds may therefore cause toxic effects to surrounding species which together with the competition for natural resources, especially in the intertidal tide pools, can enhance the impacts of $A$. armata on ecosystem integrity and functioning. Given this potential as an ecosystem engineer, very common to marine macroalgae [15], it is crucial to evaluate this non-indigenous alga' effects. Although few studies addressed this problem, little is known about it. For example, it was demonstrated that $A$. armata halogenated metabolites deterred feeding by two marine mesograzers (Hyale nigra and juvenile abalone Haliotis rubra) [16]. Exposure to its exudate caused physiological status impairment in exposed Palaemon elegans and Gibbula umbilicalis, as well as feeding inhibition in this gastropod [17].

There is limited knowledge on the impact of toxic secondary metabolites derived from macroalgae on bivalve species, contrary to the deleterious effects of bioactive compounds and toxins produced by cyanobacteria and dinoflagelates, e.g., [18-20]. Nonetheless, the physiological status of the mussel Pinna nobilis was found to be negatively affected when colonized by the invasive red macroalga Lophlocladia lallemandi, which is known to produce lophocladines with potential cytotoxic effects [21]. Thereby, the present study arises at assessing possible effects of $A$. armata exudates on the native mussel Mytilus galloproviancialis Lamarck, 1819. This species forms large and dense mono-and multi-layered beds in the low to mid intertidal rocky shores [22,23]. M. galloprovincialis has been employed as a sentinel species for monitoring coastal environments due to its widespread distribution, abundance and sedentary lifestyle [24-27]. They have an impressive filter-feeding behaviour, being capable to uptake several waterborne contaminants, thus reflecting the impacts of different environmental disturbances, e.g., [28-31]. Furthermore, M. galloprovincialis has great ecological relevance in coastal ecosystems by playing a critical role in the water quality through the filtration of particles and excess nitrogen from the aquatic environment $[32,33]$. They are also considered important links in coastal trophic chains between bottom-dwelling organisms and phytoplankton [32]. In addition, mussel beds contribute to increasing habitat complexity and therefore biodiversity $[34,35]$, by providing shelter to a variety of organisms and nurseries of juvenile fish and crustaceans. Therefore, eventual ecological consequences may derive from M. galloprovincialis decline. Aside from its ecological importance, M. galloprovincialis has a high economic value, both in Portugal and worldwide. It is considered an important food resource for human consumption, thus being among the most harvested species and representing a significant part in the overall marine aquaculture [32,36-38].

In this sense, this work intends to understand how this mussel species respond in the presence of A. armata exudate, by evaluating its toxicity in terms of biochemical and organismal responses.

\section{Materials and Methods}

\subsection{Asparagopsis armata Sampling and Exudate Production}

A. armata (gametophyte phase) was collected by hand through free diving in the subtidal zone at the Terceira island Azores (Portugal) $\left(38^{\circ} 38^{\prime} 59.2^{\prime \prime} \mathrm{N}, 27^{\circ} 13^{\prime} 16.4^{\prime \prime} \mathrm{W}\right)$ in January 2019. The macroalgae were kept in aerated seawater tanks until next day and packed in sealed containers to be transported to the laboratory in Aveiro (Portugal). Immediately upon arrival, $A$. armata was cleared from visibly associated fauna and allocated to a tank with artificial seawater (marine RedSea ${ }^{\circledR}$ Salt premium grade) in a 1:10 proportion (salinity $35 \pm 1$, $\mathrm{pH} 8.0 \pm 0.1$, temperature $20.0 \pm 0.5^{\circ} \mathrm{C}$ ) in the dark and no aeration for $24 \mathrm{~h}$ to produce the exudate, adapted from [39-41]. These conditions were previously optimized to obtain exudate from the stressed alga without causing its death during the process. Afterwards, the 
alga was removed from the tank and the resulting media (considered as the stock solution and representing $100 \%$ of exudate) was preserved at $-20^{\circ} \mathrm{C}$, until further use.

\subsection{Mytilus galloprovincialis Sampling and Acclimatization}

M. galloprovincialis specimens ( $4 \pm 0.5 \mathrm{~mm}$ length), were collected by hand, during low tide, from the intertidal rocky shores of the Barra de Aveiro (Portugal) $\left(40^{\circ} 38^{\prime} 38.8^{\prime \prime} \mathrm{N}\right.$, $\left.8^{\circ} 44^{\prime} 44.6^{\prime \prime} \mathrm{W}\right)$. Organisms were transported from the field to the laboratory and were immediately cleaned of superficial debris and encrusting organisms. Then, they were acclimated for seven days in an aquarium containing aerated artificial seawater (salinity $35 \pm 0.5, \mathrm{pH} 8.0 \pm 0.1$, temperature $19.0 \pm 0.5{ }^{\circ} \mathrm{C}$, oxygen saturation $>80 \%$ ) with a $14 \mathrm{~h}$ light: $10 \mathrm{~h}$ dark photoperiod. No food was provided during this period.

\subsection{Lethal Toxicity Test}

After acclimatising, mussels were used in a $96 \mathrm{~h}$ static acute toxicity test with the exudate from $A$. armata, which was slowly defrosted in the dark in a $4{ }^{\circ} \mathrm{C}$ chamber, before the preparation of the solutions. Eight different exudate treatments $(0.5,1,2,4,8,16,32$ and $64 \%$ ) were tested, based on a range-finding experiment, plus an artificial seawater control. Exposure was performed in $5 \mathrm{~L}$ aquarium containing $2.5 \mathrm{~L}$ of the aerated solution with five animals each and four replicates per treatment and a $14 \mathrm{~h}$ light: $10 \mathrm{~h}$ dark photoperiod. Test parameters were salinity $35 \pm 0.5, \mathrm{pH} 8.0 \pm 0.3,19.0 \pm 0.5^{\circ} \mathrm{C}$ and oxygen saturation $>80 \%$. Mussels' mortality was daily checked through the presence of open valves that were unresponsive to stimuli.

\subsection{Sublethal Toxicity Tests}

To assess the effects of the exposure of $M$. galloprovincialis to sublethal exudate concentrations, several endpoints were considered regarding biochemical (neurophysiological, oxidative stress, energy metabolism) and organismal (clearance rate and byssal thread production) responses. After the acclimatisation period (Section 2.2), mussels (4 $\pm 0.3 \mathrm{~mm}$ length) were exposed to four nominal exudate concentrations $(0.25 ; 0.5 ; 1 ; 2 \%)$, based on the $96 \mathrm{~h}$-LC50 estimated through the survival test, plus the control, during $96 \mathrm{~h}$. Seven replicates were used per treatment with one mussel each, in $1 \mathrm{~L}$ glass flasks containing $500 \mathrm{~mL}$ of aerated solution and a $14 \mathrm{~h}$ light: $10 \mathrm{~h}$ dark photoperiod. Test parameters were salinity $35 \pm 0.5, \mathrm{pH} 8.0 \pm 0.2,19.0 \pm 0.3{ }^{\circ} \mathrm{C}$, oxygen saturation $>80 \%$.

\subsubsection{Biochemical Responses}

\section{Sample Preparation for Biomarker Analysis}

Upon exposure, M. galloprovincialis tissues (digestive gland, adductor muscle and gills) were dissected, and samples were individually homogenised on ice using a sonicator (pulsed mode of 10\%, 250 Sonifier, Branson Ultrasonics, Danbury, CT, USA).

The digestive glands were homogenised in $2000 \mu \mathrm{L}$ of ultra-pure water. From each sample, one aliquot containing $4 \%$ butylated hydroxytoluene (BHT) in methanol was used for the determination of lipid peroxidation (LPO); another sample was stored for protein carbonylation (PC) quantification. The remaining homogenate was diluted in $0.2 \mathrm{M}$ K-phosphate buffer, $\mathrm{pH} 7.4$, and centrifuged for $15 \mathrm{~min}$ at $10,000 \times g\left(4{ }^{\circ} \mathrm{C}\right)$, the post-mitochondrial supernatant (PMS) was divided into microtubes and kept in $-80^{\circ} \mathrm{C}$ until further analyses of catalase (CAT) and glutathione S-transferase (GST) activities, total glutathione (tGSH).

The adductor muscles were homogenised in $2400 \mu \mathrm{L}$ of ultra-pure water. From each individual, samples were stored for lactate dehydrogenase (LDH) activity, acetylcholinesterase (AChE) activity and tGSH determination, diluted in $0.2 \mathrm{M} \mathrm{K}$-phosphate buffer, $\mathrm{pH}$ 7.4, and centrifuged for $15 \mathrm{~min} ; 3$ aliquots were taken for the analysis of lipid, sugar and protein contents and electron transport system (ETS) activity.

The homogenisation of gills was performed in $1600 \mu \mathrm{L}$ of ultra-pure water. From each sample, one aliquot for the determination LPO with $4 \%$ BHT in methanol was stored; other 
aliquots were stored for ETS quantification; the remaining homogenate was diluted in $0.2 \mathrm{M} \mathrm{K}$-phosphate buffer, $\mathrm{pH} 7.4$, and centrifuged for $15 \mathrm{~min}$ at $10,000 \times g\left(4{ }^{\circ} \mathrm{C}\right)$ and the PMS divided into microtubes and kept in $-80{ }^{\circ} \mathrm{C}$ until further analyses of CAT and GST activities and tGSH content.

All biomarkers determinations were done in micro-assays set up in 96 well flat-bottom plates and read spectrophotometrically with the Microplate reader MultiSkan Spectrum (Thermo Fisher Scientific, Waltham, MA, USA).

Neurophysiological and Oxidative Stress Biomarkers

The Bradford method [42] was applied to determine the protein concentration of PMS, using as standard the bovine $\gamma$-globulin. AChE activity was measured using acetylthiocholine as substrate and following the absorbance increase at $412 \mathrm{~nm}$, as described by Ellman's method [43] adapted to microplate [44,45]. CAT activity was determined in the PMS by following the decomposition of the substrate $\mathrm{H}_{2} \mathrm{O}_{2}$ at $240 \mathrm{~nm}$ [46]. GST activity was measured in the PMS following the conjugation of GSH with 1-chloro-2,4-dinitrobenzene $(\mathrm{CDNB})$ at $340 \mathrm{~nm}$ [47]. tGSH content was determined in the PMS fraction using a recycling reaction of reduced glutathione (GSH) with 5,5'-dithiobis-(2-nitrobenzoic acid) (DTNB) in the presence of glutathione reductase (GR) excess at $412 \mathrm{~nm}$ [48,49]. Endogenous LPO was measured as thiobarbituric acid-reactive substances (TBARS) at $535 \mathrm{~nm}$ [50]. PC was quantified based on the reaction of 2,4-dinitrophenylhydrazine (DNPH) with carbonyl groups, according to the DNPH alkaline method described by Mesquita et al. [51] at $450 \mathrm{~nm}$.

Samples for LDH determination were submitted to 3 freezing/melting cycles, centrifuged at $1000 \times \mathrm{g}$ for $10 \mathrm{~min}$ at $4{ }^{\circ} \mathrm{C}$. The supernatant was used to determine $\mathrm{LDH}$ activity by following the NADH oxidation caused by pyruvate consumption at $340 \mathrm{~nm}$ [52], adapted to microplate [53].

\section{Cellular Energy Allocation (CEA)}

$\mathrm{CEA}$ value is calculated as $\mathrm{CEA}=\mathrm{Ea} / \mathrm{Ec}$ [54], whereas Ea is the energy available (the sum of sugars, lipids and proteins) and $\mathrm{Ec}$ is the aerobic energy production (estimated as ETS activity) and were determined by the methods described by De Coen and Janssen [55] with slight modifications for microplate [56]. Total lipid content was determined by adding chloroform, methanol and ultra-pure water in a 2:2:1 proportion. After centrifugation, $\mathrm{H}_{2} \mathrm{SO}_{4}$ was added to the organic phase of each sample in clean glass tubes and were incubated at $200{ }^{\circ} \mathrm{C}, 15 \mathrm{~min}$. The absorbance was measured at $375 \mathrm{~nm}$ using tripalmitin as a lipid standard. $15 \%$ TCA was added to $300 \mu \mathrm{L}$ of homogenate and incubated for $10 \mathrm{~min}$ at $-20^{\circ} \mathrm{C}$. After centrifugation $\left(1000 \times g\right.$ for $10 \mathrm{~min}$ at $\left.4{ }^{\circ} \mathrm{C}\right)$, carbohydrates quantification was performed in the supernatant by adding $5 \%$ phenol and $\mathrm{H}_{2} \mathrm{SO}_{4}$ to the samples, with glucose as a standard, at $492 \mathrm{~nm}$. The remaining pellet was resuspended with $1 \mathrm{M} \mathrm{NaOH}$ (incubated for $30 \mathrm{~min}$ at $60^{\circ} \mathrm{C}$ ) and then neutralised with $1.67 \mathrm{HCL}$. Total protein content was quantified in this fraction following the Bradford method [42], at $520 \mathrm{~nm}$ and using bovine serum albumin as a standard. These energy available fractions were converted into energetic equivalent values using the corresponding energy of combustion: $39,500 \mathrm{~mJ} / \mathrm{g}$ lipids, $17,500 \mathrm{~mJ} / \mathrm{g}$ glycogen, $24,000 \mathrm{~mJ} / \mathrm{g}$ protein [57].

ETS activity was assessed using the INT (Iodonitrotetrazolium) reduction assay, measuring the rate of INT reduction in the presence of the nonionic detergent Triton X-100, at $490 \mathrm{~nm}$. The stoichiometrical relationship in which for $2 \mu \mathrm{mol}$ of formazan formed, $1 \mu \mathrm{mol}$ of oxygen is consumed was applied to calculate the cellular oxygen consumption rate. The specific oxyenthalpic equivalent for an average lipid, protein and carbohydrate mixture of $480 \mathrm{~kJ} / \mathrm{mol} \mathrm{O}_{2}$ was used to convert the final Ec value into energetic equivalents [57].

\subsubsection{Organismal Responses}

Clearance Rate

Clearance rate estimates the volume of water cleared of particles by the mussel per hour [58] and this way evaluates their filter-feeding behaviour. For this procedure, 
the green microalga Isochrysis galbana (Haptophyta) was used as a food item for mussels since it is representative of the marine phytoplankton communities and is known to be well ingested by bivalves. I. galbana was cultivated using the GoldMedium (aqualAlgae ${ }^{\circledR}$ ) prepared according to manufacturer instructions. Cultures were maintained under the same conditions as mentioned by Kaczerewska et al. [59]. To create the growth curve, a dilution series with a factor of two (with eleven points) was used. The cell density was then determined by direct counting in a Neubauer hemocytometer using an optical microscope and, by fluorescence ( $\lambda_{\text {excitation }}: 475 \pm 20 \mathrm{~nm} ; \lambda_{\text {emission }}: 645 \pm 40 \mathrm{~nm}$ ) in a microplate reader (Biotek ${ }^{\circledR}$ Synergy HT, VT, USA) [59]. The initial cell density was approximately $10^{6}$ cells $/ \mathrm{mL}$ and the linear regression equation used to convert fluorescence $(\mathrm{X})$ into microalgae cell density (cells/mL, as cell number per millilitre) (Y) was:

$$
Y=465.17 X-500,951\left(r^{2}=0.9938\right)
$$

Mussels were transferred, after exposure, to glass flasks containing $300 \mathrm{~mL}$ of new artificial seawater (conditions aforementioned) for $30 \mathrm{~min}$ to allow the opening of the valves so that the feeding starts in the same conditions for all organisms. Then, about $4.5 \times 10^{6}$ cells $/ \mathrm{mL}$ of the microalga I. galbana were added and the aeration was maintained to prevent the algae from settling. Three flasks were used to monitor I. galbana concentration over time, following the same procedure though without mussels. The number of algal particles per $\mathrm{mL}$ was quantified through fluorescence measurements of $2 \mathrm{~mL}$ subsamples of overlying seawater collected at 0,10, 20, 40, 60, 120 and $180 \mathrm{~min}$. Fluorescence was then converted into cell density (using the mentioned regression equation). The clearance rate was determined through the following formula [60]:

$$
\mathrm{CR}\left(\mathrm{Lh}^{-1}\right)=\left(\left(\ln \mathrm{C}_{0}-\ln \mathrm{C}_{\mathrm{t}}\right) / \mathrm{t}(\mathrm{h})\right) \times \operatorname{Vol}(\mathrm{L})
$$

where $C R$ is the clearance rate, $C_{0}$ and $C_{t}$ are concentrations of cells at $t=0$ and at a given time $(t=t)$, respectively; $t$ is the time elapsed since $t=0$ and $\mathrm{Vol}$ is the volume of water.

\section{Byssal Thread Production}

The byssal thread production is a good physiological biomarker considering mussels' general stress conditions [61]; therefore, the number of produced byssal threads and the attachment efficiency to the flask by each individual were assessed. After the $96 \mathrm{~h}$ of exposure to the different treatments $(0 ; 0.25 ; 0.5 ; 1 ; 2 \%)$, the number of functional byssuses produced by each individual was counted and their byssal attachment strength (i.e., the force necessary for detachment) was manually evaluated while still immersed in the solutions to avoid modification of the mechanical properties of the byssus by air-dryness conditions. Four attachment strengths were considered: strong, medium, weak and detach.

\subsection{Data Analysis}

Data from the lethal toxicity test were analysed using GraphPad Prism version 6.00 for Windows (GraphPad Software, La Jolla, CA, USA).

All variables were assessed for normality using the Kolmogorov-Smirnov test and Levene's test verified the homoscedasticity of data $(p>0.05)$. Biochemical and byssus production data were analysed through one-way analysis of variance (ANOVA) followed by multiple comparisons with Dunnett's post hoc test to discriminate statistically significant differences between $A$. armata exudate treatments and the non-exposed control (IBM SPSS Statistics 26). For data showing no normal distribution, the non-parametric test KruskalWallis one-way analysis of variance on ranks was used, followed by Dunn's test.

A linear mixed model was used to investigate the influence of $A$. armata exudate concentration on M. galloprovincialis clearance rate over time. Exudate concentration and time were considered as fixed effects in the model, while animal ID as a random effect to consider the repeated measures. This analysis was performed in R software v4.0.0 [62] using Ime4 package v1.1-23 [63]. 


\section{Results}

\subsection{Lethal Toxicity Test}

The $\mathrm{LC}_{50}$ for M. galloprovincialis was 3.667\% (95\% CI: 1.820-7.387\%) after $96 \mathrm{~h}$ of exposure to A. armata exudate, no mortality occurred in the control treatments. Based on this concentration, the sublethal concentrations were determined to the following endpoints.

\subsection{Sublethal Toxicity Tests}

\subsubsection{Biochemical Responses}

Neurophysiological and Oxidative Stress Biomarkers

Considering the digestive gland, there were no alterations in the levels of LPO (One Way ANOVA, $\mathrm{F}_{4,30}=0.774, p=0.551$ ) and PC (Kruskal-Wallis, $H=2.276$, d.f. $=4, p=0.685$ ) in mussels exposed to A. armata exudate (Figure 1). On their turn, the activity of CAT (One Way ANOVA, $\mathrm{F}_{4,30}=1.081, p=0.383$ ), $\mathrm{tGSH}$ (One Way ANOVA, $\mathrm{F}_{4,30}=1.316, p=0.287$ ) and GST (One Way ANOVA, $\mathrm{F}_{4,30}=0.664, p=0.622$ ) were also not affected (Figure 1 ).
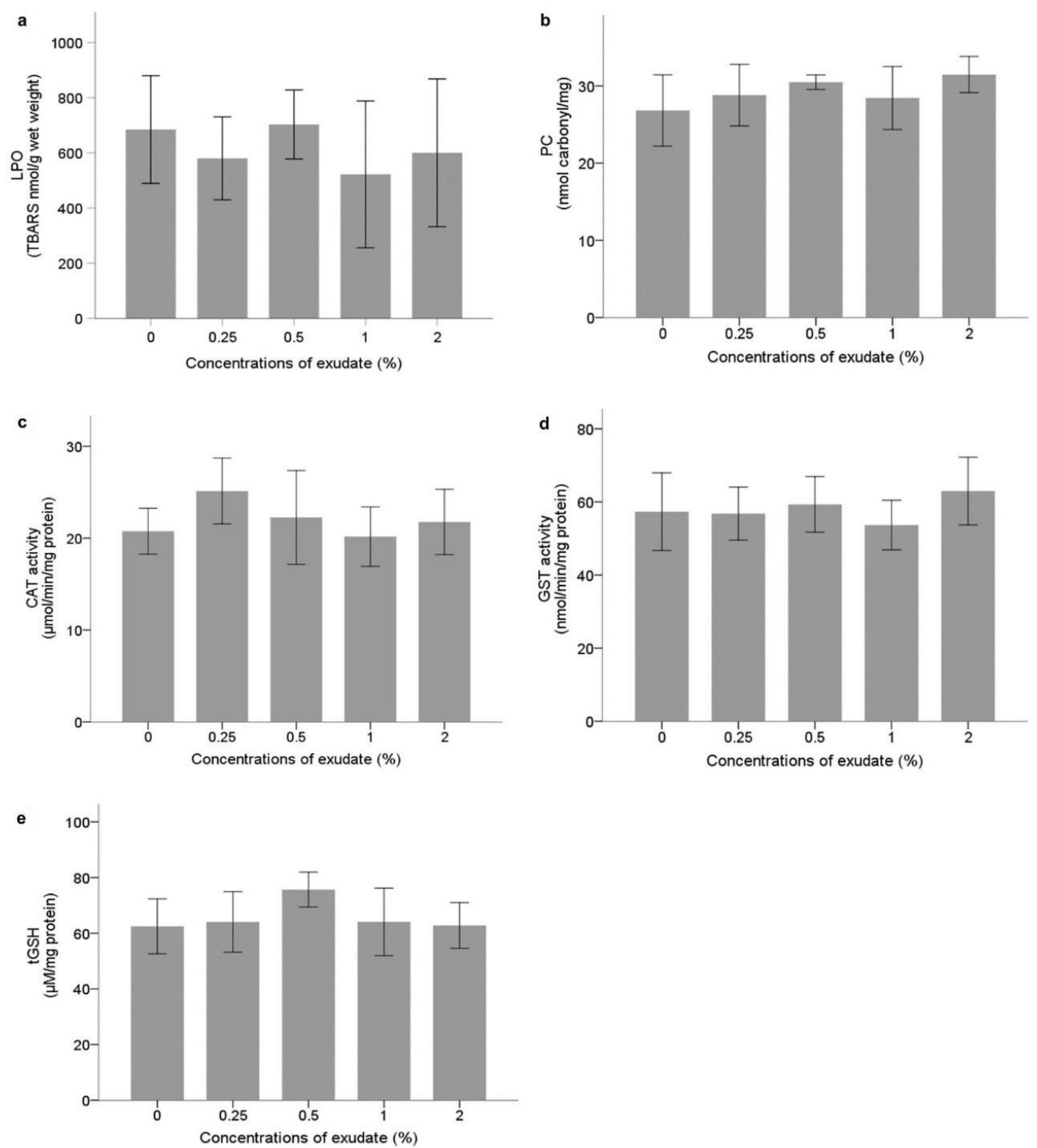

Figure 1. Oxidative stress biomarkers of Mytilus galloprovincialis digestive gland after $96 \mathrm{~h}$ of exposure to Asparagopsis armata exudate. (a) Lipid Peroxidation (LPO); (b) Protein Carbonylation (PC); (c) Catalase (CAT); (d) Glutathione-S-Transferase (GST); (e) Total Glutathione (tGSH). All values are presented as mean $\pm \mathrm{SE}$. 
In the muscle, the levels of tGSH increased in mussels exposed to the exudate, when compared to the control treatment $(0 \%$, Figure $2 \mathrm{a})$, this increase was significant at $0.5 \%$ and $2 \%(51.0 \pm 13.5 \mu \mathrm{M} / \mathrm{mg}$ prot vs. $91.8 \pm 40.5$ and $84.9 \pm 27.0 \mu \mathrm{M} / \mathrm{mg}$ protein, respectively; Kruskal-Wallis, $H=9.681$, d.f. $=4$; post-hoc analysis, $p<0.05$ ). A similar pattern was observed in the activity of AChE (Figure $2 b$ ), which significantly increased in the concentration $0.5 \%$ ( $2.756 \pm 0.802 \mathrm{nmol} / \mathrm{min} / \mathrm{mg}$ prot vs. $5.027 \pm 1.909 \mathrm{nmol} / \mathrm{min} / \mathrm{mg}$ prot; One Way ANOVA, $\mathrm{F}_{4,28}=3.065$; post-hoc analysis, $p=0.009$ ).
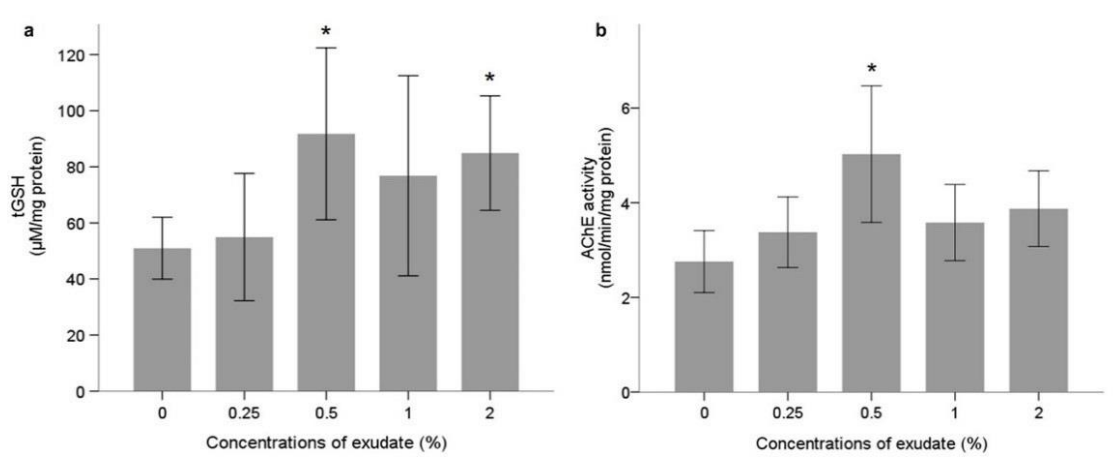

Figure 2. (a) Levels of total glutathione (tGSH) in M. galloprovincialis muscle after $96 \mathrm{~h}$ of exposure; (b) Acetylcholinesterase (AChE) activity in M. galloprovincialis muscle after $96 \mathrm{~h}$ of exposure. All values are presented as mean $\pm \mathrm{SE}$. ${ }^{*}$ denotes a statistically significant difference compared to control $(0 \%)$.

Regarding the gills (Figure 3), no alterations were detected for LPO (One Way ANOVA, $\mathrm{F}_{4,29}=0.708, p=0.593$ ), CAT (One Way ANOVA, $\mathrm{F}_{4,30}=3.855$, post-hoc analysis, $p>0.05$ ) and GST (Kruskal-Wallis, $H=6.211$, d.f. $=4, p=0.184$ ), with the exception of $\mathrm{tGSH}$, which levels decreased significantly in mussel exposed to $1 \%$ and $2 \%$ of A. armata exudate $(39.0 \pm 14.6 \mu \mathrm{M} / \mathrm{mg}$ prot vs. $19.4 \pm 7.8$ and $16.7 \pm 12.9 \mu \mathrm{M} / \mathrm{mg}$ prot, respectively; KruskalWallis, $H=11.049$, d.f. $=4$; post-hoc analysis, $p<0.05$ ).
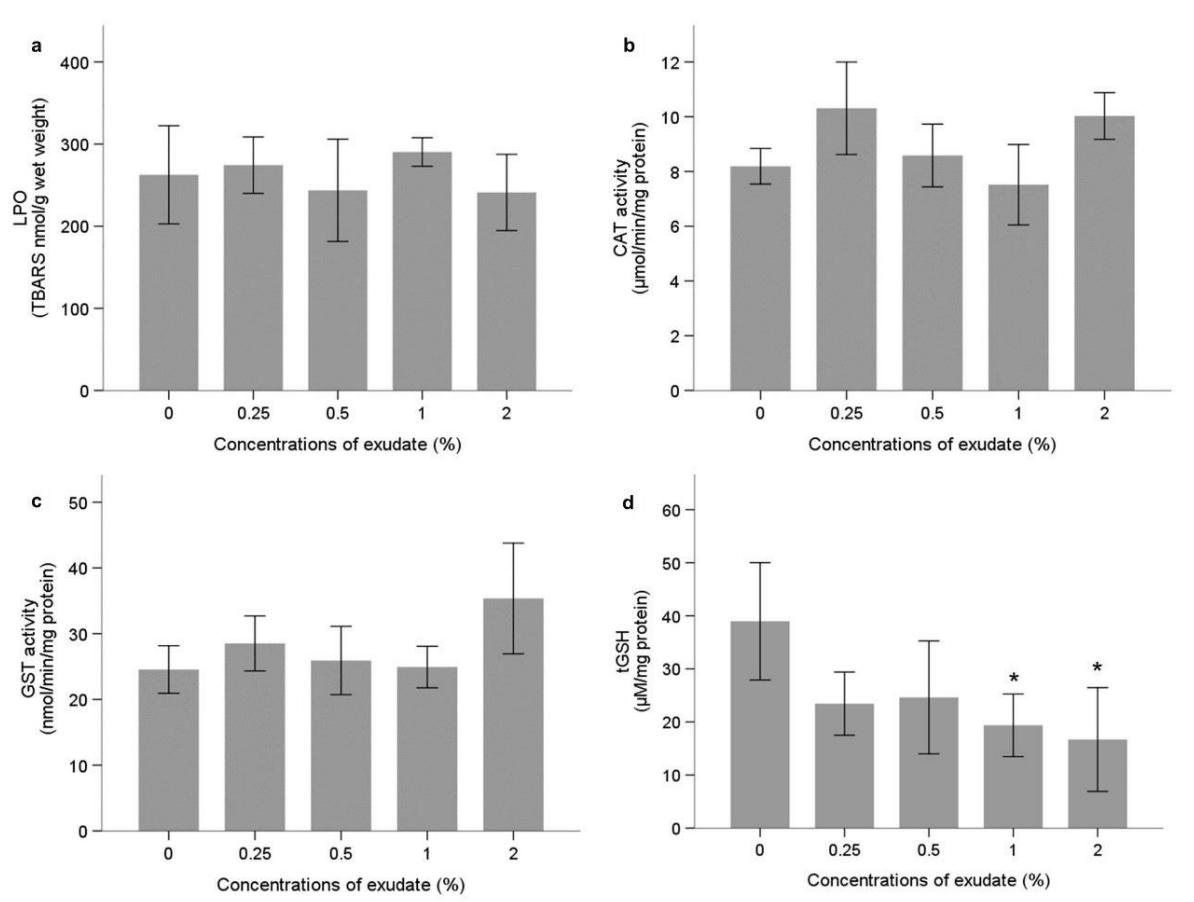

Figure 3. Oxidative stress biomarkers of M. galloprovincialis gills after $96 \mathrm{~h}$ of exposure to A. armata exudate. (a) Lipid Peroxidation (LPO); (b) Catalase (CAT); (c) Glutathione-S-Transferase (GST); (d) Total Glutathione (tGSH). All values are presented as mean $\pm \mathrm{SE}$. * denotes a statistically significant difference compared to control $(0 \%)$. 


\section{Energy Metabolism}

The activity of LDH (One Way ANOVA, $\mathrm{F}_{4,27}=0.454, p=0.768$ ) in muscles was not affected in M. galloprovincialis exposed to A. armata exudate (Figure 4a).

Although the lipid content in muscle slightly decreased in mussels exposed to $0.25 \%$ of exudate, it increased in the other concentrations, being this rise significant at $2 \%$ $\left(88.2 \pm 38.2 \mathrm{~mJ} \mathrm{lip} / \mathrm{mg}\right.$ tissue vs. $150.6 \pm 50.0 \mathrm{~mJ} \mathrm{lip} / \mathrm{mg}$ tissue; One Way ANOVA, $\mathrm{F}_{4,29}=6.277 ;$ post-hoc analysis, $p=0.012$, Figure $4 b$ ). Sugars (One Way ANOVA, $\mathrm{F}_{4,30}=0.169, p=0.953$ ) and proteins (One Way ANOVA, $\mathrm{F}_{4,30}=2.289, p=0.083$ ) were not altered (Figure $4 \mathrm{c}, \mathrm{d}$ ).

In the muscle, the aerobic energy production, measured as ETS activity, increased significantly in individuals exposed to exudate $0.5 \%, 1 \%$ and $2 \%$ concentrations of compared to the control (Kruskal-Wallis, $H=12.544$, d.f. $=4$; post-hoc analysis, $p<0.05$; Figure 4e). In line with the few changes previously observed for antioxidant defences, ETS activity was not altered in the gills (One Way ANOVA, $F_{4,30}=1.588, p=0.203$ ) (Figure 5).

In the final balance of CEA, all treatments exhibited a decrease on the energy budget of $M$. galloprovincialis compared to that of the control; this decrease was significant in the $0.25 \%$ and $0.5 \%$ treatments (Kruskal-Wallis, $H=10.844$, d.f. $=4$, post-hoc analysis $p<0.05$ ) (Figure 4f).
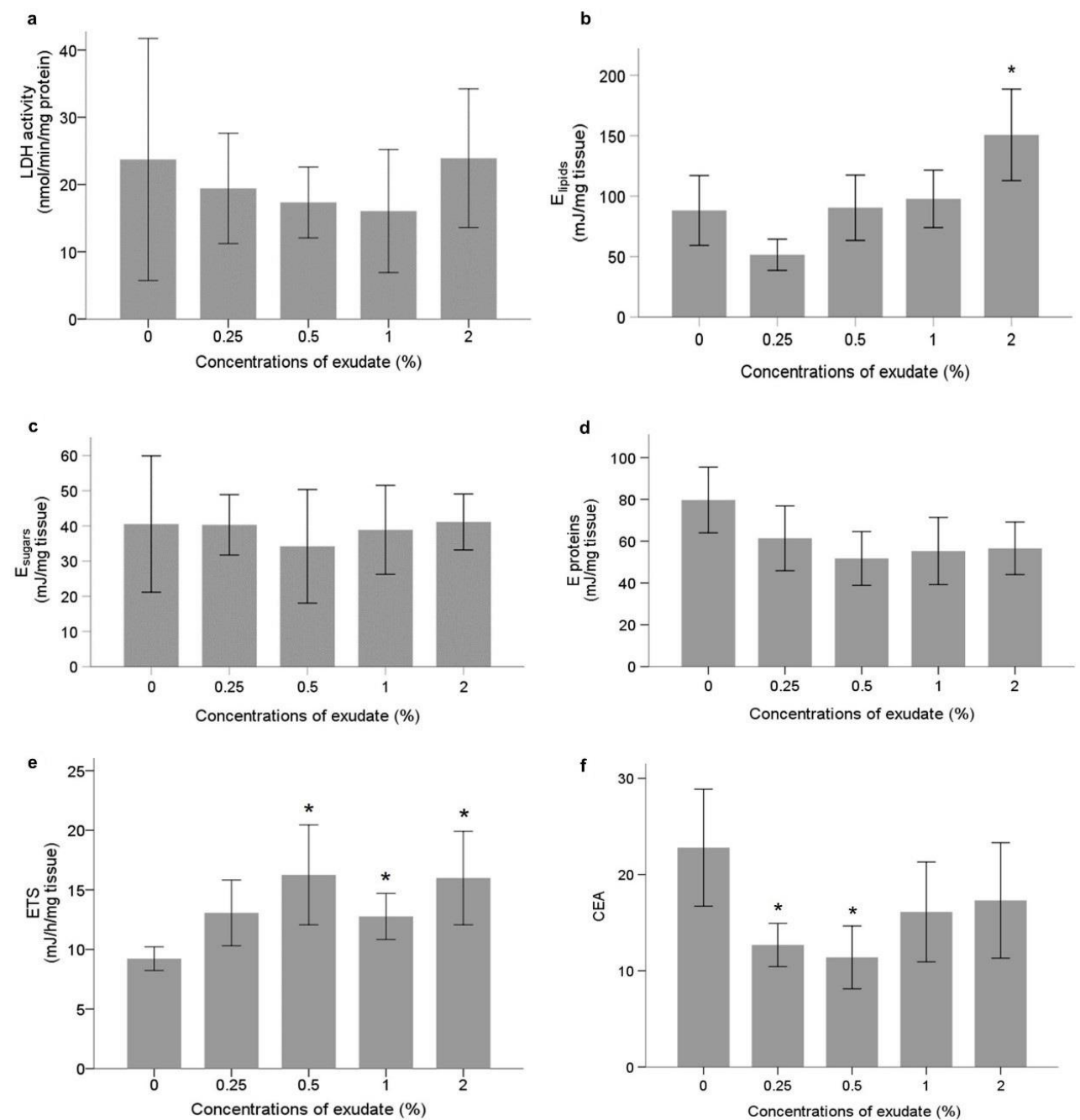

Figure 4. Energy metabolism biomarkers of M. galloprovincialis muscle after $96 \mathrm{~h}$ of exposure to A. armata exudate. (a) Lactate dehydrogenase (LDH); (b) Lipids content ( $\left.\mathrm{E}_{\text {lipids }}\right)$; (c) Sugars content (Esugars); (d) Proteins content ( $\left.\mathrm{E}_{\text {proteins }}\right)$; (e) Electron transport system (ETS); (f) Cellular energy allocation (CEA). All values are presented as mean \pm SE. * denotes a statistically significant difference compared to control $(0 \%)$. 


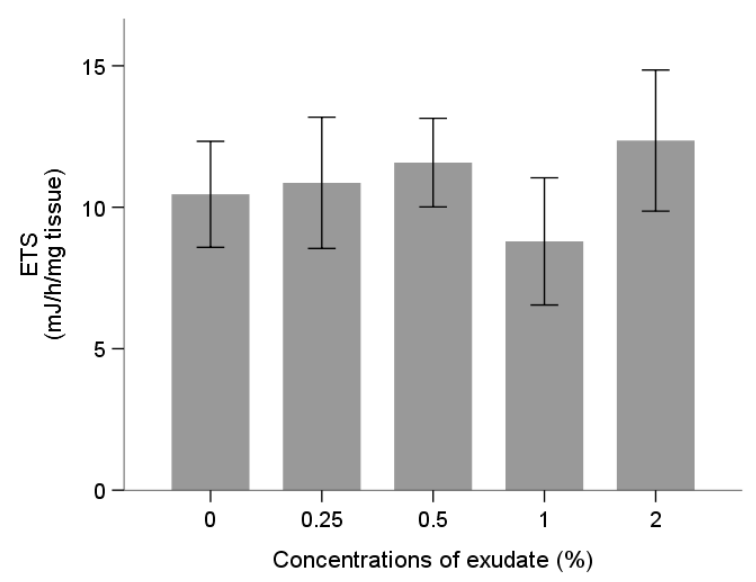

Figure 5. Electron transport system (ETS) in M. galloprovincialis gills after $96 \mathrm{~h}$ of exposure to A. armata exudate.

\subsubsection{Organismal Responses}

Clearance Rate

To evaluate the filtration performance of $M$. galloprovincialis after a 96-h exposure to A. armata exudate, the CR of each mussel was estimated (Figure 6). The cell density of I. galbana remained consistent in the vessels (without mussel) used to monitor its growth over the $3 \mathrm{~h}$ of experiment.

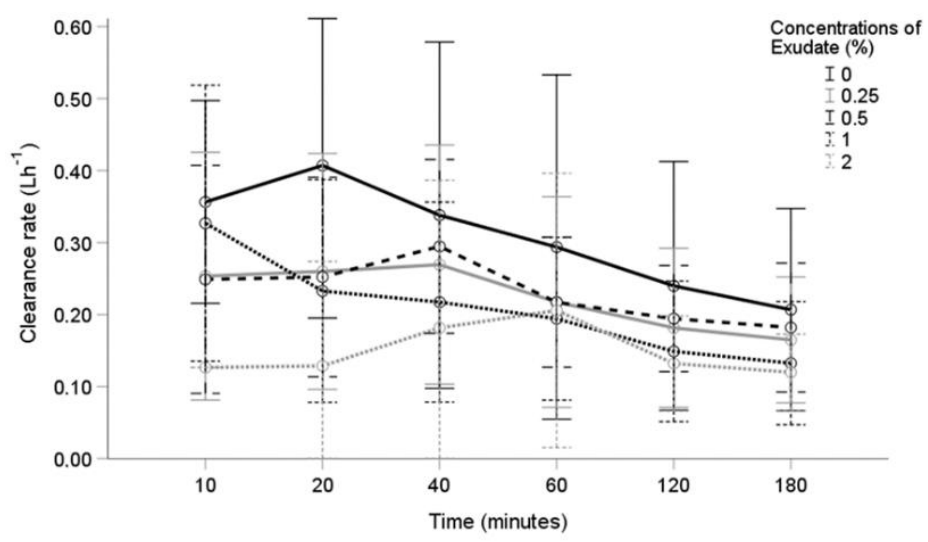

Figure 6. M. galloprovincialis clearance rates $\left(\mathrm{Lh}^{-1}\right)$ exposed to different $A$. armata exudate concentrations over time.

In all evaluated times (in which the cell density of I. galbana was measured), the CR means were higher in the controls (from 0.41 to $0.21 \mathrm{Lh}^{-1}$, Figure 6). Specifically, mussels exposed to the highest exudate concentration (2\%) generally exhibited the lowest CR means (between 0.12 and $0.21 \mathrm{Lh}^{-1}$ ) except for the $60 \mathrm{~min}$, in which the CR mean was lower in mussels of the $1 \%$ treatment (Figure 6).

The linear mixed model showed that mussels' CR decreased significantly with increased concentrations of $A$. armata exudate $(p<0.05$, Table 1$)$, it also displayed a significant tendency of CR decreasing with time (time $p<0.001$, Table 1 ). In addition, there is a significant interaction between time and exudate concentration, displaying that the CR differs significantly between distinct concentrations of exudate (exudate concentration*time interaction $p<0.05$, Table 1 ). 
Table 1. Results of the linear mixed model on M. galloprovincialis clearance rates $\left(\mathrm{Lh}^{-1}\right)$ exposed to A. armata exudate over time. Significant at $p<0.05$ and $p<0.001$. "exudate concentration * time" term represents the interaction between these two fixed effects.

\begin{tabular}{ccccc}
\hline Fixed Effects & Estimate & Std. Error & t Value & $p$-Value \\
\hline intercept & $3.307 \times 10^{-1}$ & $3.328 \times 10^{-2}$ & 9.939 & $<0.001$ \\
\hline exudate concentration & $-8.422 \times 10^{-2}$ & $3.404 \times 10^{-2}$ & -2.474 & $<0.05$ \\
\hline time & $-8.444 \times 10^{-4}$ & $1.221 \times 10^{-4}$ & -6.914 & $<0.001$ \\
\hline $\begin{array}{c}\text { exudate concentration * } \\
\text { time }\end{array}$ & $2.929 \times 10^{-4}$ & $1.293 \times 10^{-4}$ & 2.265 & $<0.05$ \\
\hline
\end{tabular}

\section{Byssal Thread Production}

After the 96-h exposure, M. galloprovincialis secretion of byssal threads was affected, since the total number of newly secreted functional byssus tended to decrease along the gradient of $A$. armata exudate concentrations (Figure 7), this decrease was significant at 1 and $2 \%$ treatments (Kruskal-Wallis, $H=10.528$, d.f. $=4$, post-hoc analysis, $p<0.05$ ).

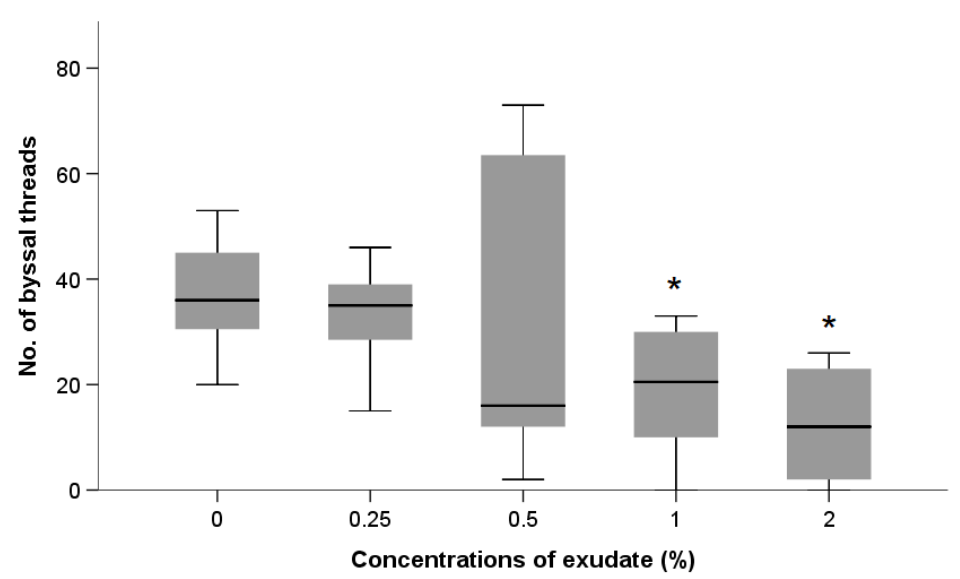

Figure 7. Number of byssal threads produced by M. galloprovincialis during $96 \mathrm{~h}$ of exposure to different concentrations of $A$. armata exudate. * denotes a statistically significant difference compared to control $(0 \%)$.

In addition, there was a significant reduction in their byssal attachment strength (Fisher exact test, $p=0.025$ ), as represented in Figure 8).

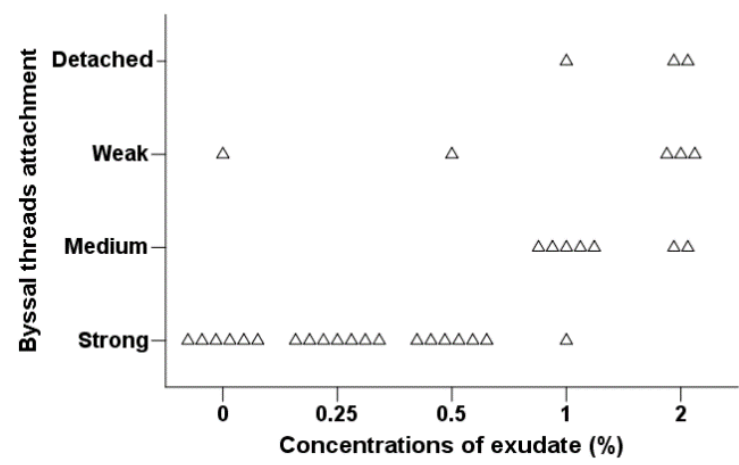

Figure 8. Byssal attachment strength on threads produced by M. galloprovincialis during $96 \mathrm{~h}$ to different concentrations of $A$. armata exudate. $\Delta$ represents each mussel. 


\section{Discussion}

The present study focused on the exposure of M. galloprovincialis to different concentrations of the exudate of $A$. armata and helped to evaluate the potential impact on the local ecosystems' integrity promoted by the presence of this invasive macroalga. Although there is evidence that the main effects may be a consequence of the biologically-active metabolites present in the A. armata exudate with strong antiherbivore, antifungal and antibiotic activity [16,64-66], especially volatile halocarbons such as bromoform, dibromomethane, 1,2-di-bromoethylene, dibromochloromethane and tribromoethylen [39], there is still a poor understanding on the impact this invasive seaweed may have in the surrounding biota. This is particularly important in the microenvironments within intertidal pools due to the encountered extreme conditions and where major algal blooms may form, especially in late spring/early summer, when the temperature starts to rise [2].

The lethal toxicity test demonstrated that the exudate produced by $A$. armata might be toxic to M. galloprovincialis compromising their survival even in short exposures. Mussels' survival decreased to $50 \%$ when exposed to only about $3.67 \%$ of exudate. Similar $96 \mathrm{~h}-\mathrm{LC}_{50}$ values were reported by Silva et al. [17] for the gastropod G. umbilicalis $(2.79 \%)$ and the prawn P. elegans (5.04\%). Another study comparing the communities of peracarid species inhabiting A. armata and Corallina elongata, a red macroalga native from the Atlantic coast and abundant in the subtidal zone of Azores [67], showed that even though A. armata hosts a diversity of crustacean assemblages [6], its presence might lead to an impoverishment of epifaunal peracarid. Along the Atlantic coast and the Iberian Peninsula, the species richness was higher in C. elongata comparing to A. armata, especially for isopods [3].

Moreover, marine macroalgae are considered a possible source of reactive oxygen species (ROS), especially when under stress [68], compromising the organisms exposed to the exuded halogenated compounds. The short exposure of M. galloprovincialis to sublethal exudate concentrations caused no oxidative damage in the digestive gland of mussels since the levels of LPO and PC were not affected by the increase of exudate concentrations. In the same tissue, no alteration was detected in the activity of the enzymatic antioxidant CAT, the enzymatic and non-enzymatic antioxidants GST and tGSH that have the main role in phase II of the biotransformation of reactive oxygen species and detoxification [69].

Oxidative stress-related biomarkers were also assessed in mussels' gills since these organs can strongly reflect the adverse environmental impact on the animals as they are directly exposed to surrounding factors due to their large surface and role in gas exchange and feeding [70]. Although most biomarkers were not affected (LPO, CAT, GST and ETS), tGSH levels declined in exudate-exposed individuals. The increased consumption in tGSH allowed to counteract increased oxidative stress and avoid oxidative damage.

In its turn, the significant increase in the levels of tGSH and ETS activity in M. galloprovincialis muscles suggests an increment of non-enzymatic antioxidant capacity, and consequently increased aerobic energy production, to cope with potential pro-oxidant compounds produced at higher exudate concentrations. This energy consumption led to a significant decrease in the energy budget of exposed mussels. Interestingly, an increase in total lipid content was observed at the highest tested exudate concentrations. Lipids are essential constituents of biologically active molecules as well as important energy reserves in bivalves. Although we did not measure some peroxisomal enzymes (such as CAT) in the muscle tissue, a correlation between lipids metabolism and peroxisomal enzyme activities has been previously described [71]. On the other hand, and in agreement with our results, an increase in lipid content of G. umbilicalis exposed to A. armata exudate was observed and related with a concomitant decrease in feeding activity, leading to less energy expenditure [17]. On the other hand, the enzymatic activity of LDH, that plays an important role in the anaerobic pathway of energy production and is responsible for the reduction of pyruvate to lactate in glycolysis [72], was not altered. A. armata exudate caused an induction in the activity of the neurotoxicity biomarker AChE, mainly in an intermediate concentration. Hormesis response after exposure to several contaminants has been observed for AChE activity, mainly in the freshwater crustacean Daphnia magna, 
e.g., [73], but also verified in in vitro testing with cell cultures [74]. This response may reveal the activation of a compensatory mechanism allowing for plasticity in response to moderate adverse environments [75]. Hormesis responses after exposure to organic compounds were also observed regarding other oxidative stress-related biomarkers in marine bivalves, such as CAT activity of Crassostrea gigas or GSH levels of M. edulis [76]. This enzyme plays a main role in regulating cholinergic neurotransmissions [77,78], therefore adverse effects on AChE may disrupt many essential nervous system functions. The final balance of the energy budget of exposed animals reflects the use of energy reserves for the antioxidant defence system and behaviour and byssus development, highlighting a higher consumption of lipids at lower concentrations of exudate.

In relation to the clearance rate, data revealed that the ability of $M$. galloprovincialis to filter was clearly affected by the individuals exposed to $A$. armata exudate. Immediately after $10 \mathrm{~min}$, mussels from the control treatment cleared the microalgae cells more efficiently than the organisms exposed to the exudate, this difference remained during the test timeline, although the values ended up converging at $180 \mathrm{~min}$. This clearance rate decline may be the result of behavioural impairment, which is in accordance with the observed changes in AChE activity. One possible explanation for these results may be related to a prolonged valve closure that bivalves usually activate as a defence mechanism resulting in a decreased feeding activity [58]. On the other hand, the bioactive compounds present in the exudate may also pose a direct effect on the gills' tissues also contributing to a filtration reduction. Similar responses on clearance rate were also reported in different bivalve species exposed to metals [58,79], pharmaceuticals [80,81], micro- and nanoplastics $[82,83]$, but also to other natural toxins [18-20]. In fact, Comeau et al. [84] demonstrated behavioural alterations in terms of valve activity in M. galloprovincialis exposed to the dinoflagellate Alexandrinum minutum. Prasertiya et al. [85] also detected changes in Mytilus edulis valve opening in response to a pigment released by the diatom Haslea ostrearia. The present findings suggest that the presence of $A$. armata may impact the suspension-feeding process in M. galloprovincialis, compromising not only their individual performance, fitness and even survival, but also leading to magnified consequences on this important intertidal community. By decreasing their feeding activity, these individuals will grow less and possibly mature later, with potential consequences to the mussel population dynamics. Decreased feeding may also reflect into a lower nutritional value to their predators, including human consumers. In addition, their pivotal role as a water filterer may be compromised under exposure to $A$. armata exudate, as well as the critical ecosystem service they provide on water quality improvement and nutrient cycling.

Furthermore, the mechanism of byssus secretion in M. galloprovincialis is influenced by several endogenous and exogenous factors (e.g., related to the hydrodynamic character of the environment, available food resources and reproductive status) [86]. Byssus promotes mussels' ability to firmly anchor to a wide range of solid surfaces, including to each other [87]. Any interference with the byssogenesis can compromise mussels' attachment to the substratum, making them more susceptible to natural stressors such as predation and strong wave action onto the shores. In this sense, this study suggests that the presence of A. armata might increase the risk of mussels' dislodgment, making them more vulnerable to tides, waves and potential predators, since the byssal thread formation was impaired in individuals exposed to the alga exudate. Mussels produced less functional byssus which in turn had weaker attachment strength when compared to the non-exposed individuals. Consequently, M. galloprovincialis beds may be particularly endangered, which raises important concerns as they provide vital services such as coastline protection and complex habitat, providing food and shelter to other coastal species [88]. This impact can thus lead to potential damage to economic activities depending on this species [88].

\section{Conclusions}

In conclusion, antioxidant defences were induced in M. galloprovincialis in response to the exudate of $A$. armata, coupled with increased energy consumption, with a consequent 
decline in cellular energy allocation. The exudate also impaired mussels' clearance rate and byssal thread production, compromising their feeding activity and ability to stay attached to the subtracts, which are essential for their survival. This study emphasises the problem of invasive seaweeds in the native ecosystems, namely the release of potential secondary metabolites that might be toxic to native species, leading to potential deleterious ecological and economic consequences in coastal environments.

Author Contributions: Conceptualization, S.D.C., H.C.V., J.M.M.O. and M.D.B.; methodology, S.D.C., H.C.V., J.M.M.O., R.J.M.R., A.C.M.R. and M.D.B.; formal analysis, S.D.C. and A.C.M.R.; investigation, S.D.C., H.C.V., J.M.M.O., S.F.S.P., A.C.M.R. and M.D.B.; resources, R.J.M.R., A.M.V.M.S. and M.D.B.; writing—original draft preparation, S.D.C.; writing—review and editing, S.D.C., H.C.V., J.M.M.O., S.F.S.P., R.J.M.R., A.C.M.R., A.M.V.M.S., M.D.B.; supervision, M.D.B.; project administration, M.D.B.; funding acquisition, A.M.V.M.S. and M.D.B. All authors have read and agreed to the published version of the manuscript.

Funding: This research was funded through CESAM (UIDB/50017/2020 + UIDP/50017/2020), with financial support from FCT/MEC through national funds. The authors are thankful for the financial support by the project INSIDER (PTDC/CTA-AMB/30495/2017 and POCI-01-0145-FEDER-030495) funded by FEDER, through COMPETE2020-Programa Operacional Competitividade e Internacionalização (POCI), and by national funds (OE), through FCT/MCTES. The authors also thank FCT and POPH/FSE (Programa Operacional Potencial Humano/Fundo Social Europeu) for the doctoral grant of H.C.V. (PD/BD/127808/2016). M.D.B. and R.J.M.R. are funded by national funds (OE), through FCT, I.P., in the scope of the framework contract foreseen in the numbers 4,5 and 6 of the article 23, of the Decree-Law 57/2016, of August 29, changed by Law 57/2017, of July 19.

Institutional Review Board Statement: Not applicable.

Informed Consent Statement: Not applicable.

Data Availability Statement: The data presented in this study is available in the current manuscript, raw data is available on request from the corresponding author.

Conflicts of Interest: The authors declare no conflict of interest.

\section{References}

1. Thomsen, M.S.; Wernberg, T.; South, P.M.; Schiel, D.R. Non-native Seaweeds Drive Changes in Marine Coastal Communities Around the World. In Seaweed Phylogeography: Adaptation and Evolution of Seaweeds under Environmental Change; Hu, Z.-M., Fraser, C., Eds.; Springer: Dordrecht, The Netherlands, 2016; pp. 147-185. ISBN 978-94-017-7534-2.

2. Martins, G.M.; Cacabelos, E.; Faria, J.; Álvaro, N.; Prestes, A.C.L.; Neto, A.I. Patterns of distribution of the invasive alga Asparagopsis armata Harvey: A multi-scaled approach. Aquat. Invasions 2019, 14, 582-593. [CrossRef]

3. Guerra-García, J.M.; Ros, M.; Izquierdo, D.; Soler-Hurtado, M.M. The invasive Asparagopsis armata versus the native Corallina elongata: Differences in associated peracarid assemblages. J. Exp. Mar. Biol. Ecol. 2012, 416-417, 121-128. [CrossRef]

4. Maggs, C.A.; Stegenga, H. Red algal exotics on North Sea coasts. Helgol. Meeresunters. 1998, 52, 243-258. [CrossRef]

5. Dijoux, L.; Viard, F.; Payri, C. The more we search, the more we find: Discovery of a new lineage and a new species complex in the genus Asparagopsis. PLoS ONE 2014, 9, e103826. [CrossRef] [PubMed]

6. Pacios, I.; Guerra-García, J.M.; Baeza-Rojano, E.; Cabezas, M.P. The non-native seaweed Asparagopsis armata supports a diverse crustacean assemblage. Mar. Environ. Res. 2011, 71, 275-282. [CrossRef]

7. Katsanevakis, S.; Wallentinus, I.; Zenetos, A.; Leppäkoski, E.; Çinar, M.E.; Oztürk, B.; Grabowski, M.; Golani, D.; Cardoso, A.C. Impacts of invasive alien marine species on ecosystem services and biodiversity: A pan-European review. Aquat. Invations 2014, 9, 391-423. [CrossRef]

8. Pinteus, S.; Lemos, M.F.L.; Alves, C.; Neugebauer, A.; Silva, J.; Thomas, O.P.; Botana, L.M.; Gaspar, H.; Pedrosa, R. Marine invasive macroalgae: Turning a real threat into a major opportunity-The biotechnological potential of Sargassum muticum and Asparagopsis armata. Algal Res. 2018, 34, 217-234. [CrossRef]

9. Gibson, R.N. Intertidal Fishes. In Encyclopedia of Ocean Sciences, 2nd ed.; Steele, J.H., Ed.; Academic Press: Oxford, UK, 2001; pp. 280-285. ISBN 978-0-12-374473-9.

10. Terlizzi, A.; Felline, S.; Lionetto, M.G.; Caricato, R.; Perfetti, V.; Cutignano, A.; Mollo, E. Detrimental physiological effects of the invasive alga Caulerpa racemosa on the Mediterranean white seabream Diplodus sargus. Aquat. Biol. 2011, 12, 109-117. [CrossRef]

11. Tejada, S.; Deudero, S.; Box, A.; Sureda, A. Physiological response of the sea urchin Paracentrotus lividus fed with the seagrass Posidonia oceanica and the alien algae Caulerpa racemosa and Lophocladia lallemandii. Mar. Environ. Res. 2013, 83, 48-53. [CrossRef] [PubMed] 
12. McConnell, O.; Fenical, W. Halogen chemistry of the red alga Asparagopsis. Phytochemistry 1977, 16, 367-374. [CrossRef]

13. Kladi, M.; Vagias, C.; Roussis, V. Volatile halogenated metabolites from marine red algae. Phytochem. Rev. 2004, 3, 337-366. [CrossRef]

14. Paul, N.A.; de Nys, R.; Steinberg, P.D. Chemical defence against bacteria in the red alga Asparagopsis armata: Linking structure with function. Mar. Ecol. Prog. Ser. 2006, 306, 87-101. [CrossRef]

15. Navarro-Barranco, C.; Florido, M.; Ros, M.; González-Romero, P.; Guerra-García, J.M. Impoverished mobile epifaunal assemblages associated with the invasive macroalga Asparagopsis taxiformis in the Mediterranean Sea. Mar. Environ. Res. 2018, 141, 44-52. [CrossRef] [PubMed]

16. Paul, A.N.; de Nys, R.; Steinberg, P.D. Seaweed-herbivore interactions at a small scale: Direct tests of feeding deterrence by filamentous algae. Mar. Ecol. Prog. Ser. 2006, 323, 1-9. [CrossRef]

17. Silva, C.O.; Novais, S.C.; Soares, A.M.V.M.; Barata, C.; Lemos, M.F.L. Impacts of the Invasive Seaweed Asparagopsis armata Exudate on Energetic Metabolism of Rock Pool Invertebrates. Toxins 2021, 13, 15. [CrossRef] [PubMed]

18. Li, S.-C.; Wang, W.-X.; Hsieh, D.P.H. Effects of toxic dinoflagellate Alexandrium tamarense on the energy budgets and growth of two marine bivalves. Mar. Environ. Res. 2002, 53, 145-160. [CrossRef]

19. Castrec, J.; Soudant, P.; Payton, L.; Tran, D.; Miner, P.; Lambert, C.; Le Goïc, N.; Huvet, A.; Quillien, V.; Boullot, F.; et al. Bioactive extracellular compounds produced by the dinoflagellate Alexandrium minutum are highly detrimental for oysters. Aquat. Toxicol. 2018, 199, 188-198. [CrossRef]

20. Nielsen, P.; Krock, B.; Hansen, P.J.; Vismann, B. Effects of the DSP-toxic dinoflagellate Dinophysis acuta on clearance and respiration rate of the blue mussel, Mytilus edulis. PLoS ONE 2020, 15, e0230176. [CrossRef] [PubMed]

21. Box, A.; Sureda, A.; Deudero, S. Antioxidant response of the bivalve Pinna nobilis colonised by invasive red macroalgae Lophocladia lallemandii. Comp. Biochem. Physiol. Part C Toxicol. Pharmacol. 2009, 149, 456-460. [CrossRef]

22. Seed, R. Systematics Evolution and Distribution of Mussels Belonging To the Genus Mytilus-An Overview. Am. Malacol. Bull. 1992, 9, 123-137.

23. Musella, M.; Wathsala, R.; Tavella, T.; Rampelli, S.; Barone, M.; Palladino, G.; Biagi, E.; Brigidi, P.; Turroni, S.; Franzellitti, S.; et al. Tissue-scale microbiota of the Mediterranean mussel (Mytilus galloprovincialis) and its relationship with the environment. Sci. Total Environ. 2020, 717, 137209. [CrossRef] [PubMed]

24. Fattorini, D.; Notti, A.; Di Mento, R.; Cicero, A.M.; Gabellini, M.; Russo, A.; Regoli, F. Seasonal, spatial and inter-annual variations of trace metals in mussels from the Adriatic sea: A regional gradient for arsenic and implications for monitoring the impact of off-shore activities. Chemosphere 2008, 72, 1524-1533. [CrossRef]

25. Deudero, S.; Box, A.; Tejada, S.; Tintoré, J. Stable isotopes and metal contamination in caged marine mussel Mytilus galloprovincialis. Mar. Pollut. Bull. 2009, 58, 1025-1031. [CrossRef]

26. Regoli, F.; Pellegrini, D.; Cicero, A.M.; Nigro, M.; Benedetti, M.; Gorbi, S.; Fattorini, D.; D’Errico, G.; Di Carlo, M.; Nardi, A.; et al. A multidisciplinary weight of evidence approach for environmental risk assessment at the Costa Concordia wreck: Integrative indices from Mussel Watch. Mar. Environ. Res. 2014, 96, 92-104. [CrossRef] [PubMed]

27. Beyer, J.; Green, N.W.; Brooks, S.; Allan, I.J.; Ruus, A.; Gomes, T.; Bråte, I.L.N.; Schøyen, M. Blue mussels (Mytilus edulis spp.) as sentinel organisms in coastal pollution monitoring: A review. Mar. Environ. Res. 2017, 130, 338-365. [CrossRef]

28. Bocchetti, R.; Fattorini, D.; Pisanelli, B.; Macchia, S.; Oliviero, L.; Pilato, F.; Pellegrini, D.; Regoli, F. Contaminant accumulation and biomarker responses in caged mussels, Mytilus galloprovincialis, to evaluate bioavailability and toxicological effects of remobilized chemicals during dredging and disposal operations in harbour areas. Aquat. Toxicol. 2008, 89, 257-266. [CrossRef]

29. Serra-Compte, A.; Maulvault, A.L.; Camacho, C.; Álvarez-Muñoz, D.; Barceló, D.; Rodríguez-Mozaz, S.; Marques, A. Effects of water warming and acidification on bioconcentration, metabolization and depuration of pharmaceuticals and endocrine disrupting compounds in marine mussels (Mytilus galloprovincialis). Environ. Pollut. 2018, 236, 824-834. [CrossRef]

30. Coppola, F.; Almeida, Â.; Henriques, B.; Soares, A.M.V.M.; Figueira, E.; Pereira, E.; Freitas, R. Biochemical responses and accumulation patterns of Mytilus galloprovincialis exposed to thermal stress and Arsenic contamination. Ecotoxicol. Environ. Saf. 2018, 147, 954-962. [CrossRef] [PubMed]

31. Pinto, J.; Costa, M.; Leite, C.; Borges, C.; Coppola, F.; Henriques, B.; Monteiro, R.; Russo, T.; Di Cosmo, A.; Soares, A.M.V.M.; et al. Ecotoxicological effects of lanthanum in Mytilus galloprovincialis: Biochemical and histopathological impacts. Aquat. Toxicol. 2019, 211, 181-192. [CrossRef]

32. Shumway, S.E.; Davis, C.V.; Downey, R.; Karney, R.; Kraeuter, J.N.; Rheault, R.B.; Wikfors, G.H. Shellfish aquaculture-In praise of sustainable economies and environments. World Aquac. 2003, 34, 8-10.

33. Monteduro, R.A.; Pellizzato, F.; Sperni, L.; Pavoni, B. Contamination in Mytilus galloprovincialis by chlorinated hydrocarbons (PCBs and pesticides), PAHs and heavy metals in the lagoon of Venice. Polycycl. Aromat. Compd. 2007, 27, 437-459. [CrossRef]

34. Kristensen, L.; Stenberg, C.; Støttrup, J.; Poulsen, L.K.; Christensen, H.T.; Dolmer, P.; Landes, A.; Røjbek, M.; Thorsen, S.W.; van Deurs, M.A.; et al. Establishment of blue mussel beds to enhance fish habitats. Appl. Ecol. Environ. Res. 2015, 13, 783-796.

35. Lathlean, J.A.; McQuaid, C.D. Biogeographic Variability in the Value of Mussel Beds as Ecosystem Engineers on South African Rocky Shores. Ecosystems 2017, 20, 568-582. [CrossRef]

36. Montalto, V.; Martinez, M.; Rinaldi, A.; Sarà, G.; Mirto, S. The effect of the quality of diet on the functional response of Mytilus galloprovincialis (Lamarck, 1819): Implications for integrated multitrophic aquaculture (IMTA) and marine spatial planning. Aquaculture 2017, 468, 371-377. [CrossRef] 
37. Oliveira, J.; Castilho, F.; Cunha, Â.; Pereira, M.J. Bivalve Harvesting and Production in Portugal: An Overview. J. Shellfish Res. 2013, 32, 911-924. [CrossRef]

38. Instituto Nacional de Estatística. Estatísticas da Pesca: 2019; INE: Lisboa, Portugal, 2020; ISBN 978-989-25-0540-4. ISSN 0377-225-X.

39. Marshall, R.A.; Harper, D.B.; McRoberts, W.C.; Dring, M.J. Volatile bromocarbons produced by Falkenbergia stages of Asparagopsis spp. (Rhodophyta). Limnol. Oceanogr. 1999, 44, 1348-1352. [CrossRef]

40. Swanson, A.K.; Druehl, L.D. Induction, exudation and the UV protective role of kelp phlorotannins. Aquat. Bot. 2002, 73, 241-253. [CrossRef]

41. Bravo-Linares, C.M.; Mudge, S.M.; Loyola-Sepulveda, R.H. Production of Volatile Organic Compounds (VOCs) by temperate macroalgae: The use of Solid Phase Microextraction (SPME) coupled to GC-MS as method of analysis. J. Chil. Chem. Soc. 2010, 55, 227-232. [CrossRef]

42. Bradford, M.M. A rapid and sensitive method for the quantitation of microgram quantities of protein utilizing the principle of protein-dye binding. Anal. Biochem. 1976, 72, 248-254. [CrossRef]

43. Ellman, G.L.; Courtney, K.D.; Andres, V.; Featherstone, R.M. A new and rapid colorimetric determination of acetylcholinesterase activity. Biochem. Pharmacol. 1961, 7, 88-95. [CrossRef]

44. Guilhermino, L.; Lopes, M.C.; Carvalho, A.P.; Soares, A.M.V.M. Acetylcholinesterase Activity in Juveniles of Daphnia magna Straus. Bull. Environ. Contam. Toxicol. 1996, 57, 979-985. [CrossRef]

45. Domingues, I.; Gravato, C. Oxidative Stress Assessment in Zebrafish Larvae. Methods Mol. Biol. 2018, 1797, 477-486. [CrossRef]

46. Clairborne, A. Catalase activity. In CRC Handbook of Methods in Oxygen Radical Research; Greenwald, R.A., Ed.; CRC Press: Boca Raton, FL, USA, 1985; pp. 283-284.

47. Habig, W.H.H.; Pabst, M.J.J.; Jacoby, W.B.; Jakoby, W.B. Glutathione S-transferases. The first enzymatic step in mercapturic acid formation. J. Biol. Chem. 1974, 249, 7130-7139. [CrossRef]

48. Tietze, F. Enzymic method for quantitative determination of nanogram amounts of total and oxidized glutathione: Applications to mammalian blood and other tissues. Anal. Biochem. 1969, 27, 502-522. [CrossRef]

49. Baker, M.; Cerniglia, G.; Zaman, A. Microtiter plate assay for the measurement of glutathione and glutathione disulfide in large numbers of biological samples. Anal. Biochem. 1990, 190, 360-365. [CrossRef]

50. Bird, R.P.; Draper, H.H. Comparative studies on different methods of malonaldehyde determination. Methods Enzymol. 1984, 105, 299-305. [PubMed]

51. Mesquita, C.S.; Oliveira, R.; Bento, F.; Geraldo, D.; Rodrigues, J.V.; Marcos, J.C. Simplified 2,4-dinitrophenylhydrazine spectrophotometric assay for quantification of carbonyls in oxidized proteins. Anal. Biochem. 2014, 458, 69-71. [CrossRef]

52. Vassault, A. Lactate dehydrogenase. In Methods of Enzymatic Analysis, Enzymes: Oxireductases, Transferase; Bergmyer, M.O., Ed.; Academic Press: New York, NY, USA, 1983; pp. 118-126.

53. Diamantino, T.C.; Almeida, E.; Soares, A.M.V.M.; Guilhermino, L. Lactate dehydrogenase activity as an effect criterion in toxicity tests with Daphnia magna straus. Chemosphere 2001, 45, 553-560. [CrossRef]

54. Verslycke, T.; Ghekiere, A.; Janssen, C.R. Seasonal and spatial patterns in cellular energy allocation in the estuarine mysid Neomysis integer (Crustacea: Mysidacea) of the Scheldt estuary (The Netherlands). J. Exp. Mar. Biol. Ecol. 2004, 306, $245-267$. [CrossRef]

55. De Coen, W.; Janssen, C.R. The use of biomarkers in Daphnia magna toxicity testing. IV.Cellular Energy Allocation: A new methodology to assess the energy budget of toxicant-stressed Daphnia populations. J. Aquat. Ecosyst. Stress Recover. 1997, 6, 43-55. [CrossRef]

56. Rodrigues, A.C.M.; Gravato, C.; Quintaneiro, C.; Golovko, O.; Žlábek, V.; Barata, C.; Soares, A.M.V.M.; Pestana, J.L.T. Life history and biochemical effects of chlorantraniliprole on Chironomus riparius. Sci. Total Environ. 2015, 508, 506-513. [CrossRef]

57. Gnaiger, E. Calculation of Energetic and Biochemical Equivalents of Respiratory Oxygen Consumption. In Polarographic Oxygen Sensors. Aquatic and Physiological Applications; Gnaiger, E., Forstner, H., Eds.; Springer: Berlin/Heidelberg, Germany, 1983; pp. 337-345. ISBN 978-3-642-81865-3.

58. Chandurvelan, R.; Marsden, I.D.; Gaw, S.; Glover, C.N. Impairment of green-lipped mussel (Perna canaliculus) physiology by waterborne cadmium: Relationship to tissue bioaccumulation and effect of exposure duration. Aquat. Toxicol. 2012, 124-125, 114-124. [CrossRef] [PubMed]

59. Kaczerewska, O.; Martins, R.; Figueiredo, J.; Loureiro, S.; Tedim, J. Environmental behaviour and ecotoxicity of cationic surfactants towards marine organisms. J. Hazard. Mater. 2020, 392, 122299. [CrossRef] [PubMed]

60. Coughlan, J. The estimation of filtering rate from the clearance of suspensions. Mar. Biol. 1969, 2, 356-358. [CrossRef]

61. Stara, A.; Pagano, M.; Capillo, G.; Fabrello, J.; Sandova, M.; Vazzana, I.; Zuskova, E.; Velisek, J.; Matozzo, V.; Faggio, C. Assessing the effects of neonicotinoid insecticide on the bivalve mollusc Mytilus galloprovincialis. Sci. Total Environ. 2020, 700, 134914. [CrossRef]

62. R Core Team. R: A Language and Environment for Statistical Computing. R Foundation for Statistical Computing. 2020. Available online: https:/ / www.r-project.org/ (accessed on 9 April 2020).

63. Bates, D.; Mächler, M.; Bolker, B.; Walker, S. Fitting Linear Mixed-Effects Models using lme4. arXiv 2014, arXiv:1406.5823.

64. Genovese, G.; Tedone, L.; Hamann, M.; Morabito, M. The Mediterranean Red Alga Asparagopsis: A Source of Compounds against Leishmania. Mar. Drugs 2009, 7, 361-366. [CrossRef] [PubMed] 
65. Pinteus, S.; Alves, C.; Monteiro, H.; Araújo, E.; Horta, A.; Pedrosa, R. Asparagopsis armata and Sphaerococcus coronopifolius as a natural source of antimicrobial compounds. World J. Microbiol. Biotechnol. 2015, 31, 445-451. [CrossRef]

66. Bansemir, A.; Blume, M.; Schröder, S.; Lindequist, U. Screening of cultivated seaweeds for antibacterial activity against fish pathogenic bacteria. Aquaculture 2006, 252, 79-84. [CrossRef]

67. Neto, A. Macroalgal species diversity and biomass of subtidal communities of São Miguel (Azores). Helgol. Mar. Res. 2001, 55, 101-111. [CrossRef]

68. Liu, F.; Pang, S.J. Stress tolerance and antioxidant enzymatic activities in the metabolisms of the reactive oxygen species in two intertidal red algae Grateloupia turuturu and Palmaria palmata. J. Exp. Mar. Biol. Ecol. 2010, 382, 82-87. [CrossRef]

69. Regoli, F.; Giuliani, M.E. Oxidative pathways of chemical toxicity and oxidative stress biomarkers in marine organisms Mar. Environ. Res. 2014, 93, 106-117. [CrossRef] [PubMed]

70. D'Agata, A.; Cappello, T.; Maisano, M.; Parrino, V.; Giannetto, A.; Brundo, M.V.; Ferrante, M.; Mauceri, A. Cellular biomarkers in the mussel Mytilus galloprovincialis (Bivalvia: Mytilidae) from Lake Faro (Sicily, Italy). Ital. J. Zool. 2014, 81, 43-54. [CrossRef]

71. Cancio, I.; Ibabe, A.P.; Cajaraville, M. Seasonal variation of peroxisomal enzyme activities and peroxisomal structure in mussels Mytilus galloprovincialis and its relationship with the lipid content. Comp. Biochem. Physiol. Part C Pharmacol. Toxicol. Endocrinol. 1999, 123, 135-144. [CrossRef]

72. Shahriari, A.; Dawson, N.J.; Bell, R.A.V.; Storey, K.B. Stable Suppression of Lactate Dehydrogenase Activity during Anoxia in the Foot Muscle of Littorina littorea and the Potential Role of Acetylation as a Novel Posttranslational Regulatory Mechanism. Enzyme. Res. 2013, 461374. [CrossRef]

73. Jemec, A.; Drobne, D.; Tisler, T.; Trebse, P.; Ros, M.; Sepcić, K. The applicability of acetylcholinesterase and glutathione Stransferase in Daphnia magna toxicity test. Comp. Biochem. Physiol. C Toxicol. Pharmacol. 2007, 144, 303-309. [CrossRef]

74. Amalia, R.; Jean, A.; Loriano, B.; Stéphanie, B.-V.; Francesca, C.; Varela, C.A.; Isabelle, D.-C.; Damjana, D.; Anne-Marie, G.; Anita, J.K.; et al. Stem cells of aquatic invertebrates as an advanced tool for assessing ecotoxicological impacts. Sci. Total Environ. 2021, 144565. [CrossRef]

75. Calabrese, E.J.; Mattson, M.P. Hormesis provides a generalized quantitative estimate of biological plasticity. J. Cell Commun. Signal. 2011, 5, 25-38. [CrossRef]

76. Haque, M.N.; Eom, H.-J.; Nam, S.-E.; Shin, Y.K.; Rhee, J.-S. Chlorothalonil induces oxidative stress and reduces enzymatic activities of $\mathrm{Na}+\mathrm{K}+-$ ATPase and acetylcholinesterase in gill tissues of marine bivalves. PLoS ONE 2019, 14, e0214236. [CrossRef]

77. Ferreira, G.K.; Carvalho-Silva, M.; Gonçalves, C.L.; Vieira, J.S.; Scaini, G.; Ghedim, F.V.; Deroza, P.F.; Zugno, A.I.; Pereira, T.C.B.; Oliveira, G.M.T.; et al. 1-Tyrosine administration increases acetylcholinesterase activity in rats. Neurochem. Int. 2012, 61, 1370-1374. [CrossRef] [PubMed]

78. Fonte, E.; Ferreira, P.; Guilhermino, L. Temperature rise and microplastics interact with the toxicity of the antibiotic cefalexin to juveniles of the common goby (Pomatoschistus microps): Post-exposure predatory behaviour, acetylcholinesterase activity and lipid peroxidation. Aquat. Toxicol. 2016, 180, 173-185. [CrossRef] [PubMed]

79. Al-Subiai, S.N.; Moody, A.J.; Mustafa, S.A.; Jha, A.N. A multiple biomarker approach to investigate the effects of copper on the marine bivalve mollusc, Mytilus edulis. Ecotoxicol. Environ. Saf. 2011, 74, 1913-1920. [CrossRef]

80. Almeida, Â.; Calisto, V.; Esteves, V.I.; Schneider, R.J.; Soares, A.M.V.M.; Figueira, E.; Freitas, R. Presence of the pharmaceutical drug carbamazepine in coastal systems: Effects on bivalves. Aquat. Toxicol. 2014, 156, 74-87. [CrossRef]

81. Peters, J.R.; Granek, E.F. Long-term exposure to fluoxetine reduces growth and reproductive potential in the dominant rocky intertidal mussel, Mytilus californianus. Sci. Total Environ. 2016, 545-546, 621-628. [CrossRef]

82. Rist, S.E.; Assidqi, K.; Zamani, N.P.; Appel, D.; Perschke, M.; Huhn, M.; Lenz, M. Suspended micro-sized PVC particles impair the performance and decrease survival in the Asian green mussel Perna viridis. Mar. Pollut. Bull. 2016, 111, 213-220. [CrossRef] [PubMed]

83. Wegner, A.; Besseling, E.; Foekema, E.M.; Kamermans, P.; Koelmans, A.A. Effects of nanopolystyrene on the feeding behavior of the blue mussel (Mytilus edulis L.). Environ. Toxicol. Chem. 2012, 31, 2490-2497. [CrossRef] [PubMed]

84. Comeau, L.A.; Babarro, J.M.F.; Riobó, P.; Scarratt, M.; Starr, M.; Tremblay, R. PSP-producing dinoflagellate Alexandrium minutum induces valve microclosures in the mussel Mytilus galloprovincialis. Aquaculture 2019, 500, 407-413. [CrossRef]

85. Prasetiya, F.S.; Comeau, L.A.; Gastineau, R.; Decottignies, P.; Cognie, B.; Morançais, M.; Turcotte, F.; Mouget, J.-L.; Tremblay, R. Effect of marennine produced by the blue diatom Haslea ostrearia on behavioral, physiological and biochemical traits of juvenile Mytilus edulis and Crassostrea virginica. Aquaculture 2017, 467, 138-148. [CrossRef]

86. Babarro, J.M.F.; Reiriz, M.J.F. Secretion of byssal threads in Mytilus galloprovincialis: Quantitative and qualitative values after spawning stress. J. Comp. Physiol. B 2010, 180, 95-104. [CrossRef]

87. Silverman, H.G.; Roberto, F.F. Byssus Formation in Mytilus. In Biological Adhesive Systems: From Nature to Technical and Medical Application; von Byern, J., Grunwald, I., Eds.; Springer: Vienna, Austria, 2010; pp. 273-283. ISBN 978-3-7091-0286-2.

88. Motta, C.M.; Tizzano, M.; Tagliafierro, A.M.; Simoniello, P.; Panzuto, R.; Esposito, L.; Migliaccio, V.; Rosati, L.; Avallone, B. Biocide triclosan impairs byssus formation in marine mussels Mytilus galloprovincialis. Environ. Pollut. 2018, 241, 388-396. [CrossRef] 